\title{
PENGARUH KERAPATAN TANAMAN TERHADAP PERTUMBUHAN DAN HASIL TANAMAN SORGUM (Sorghum bicolor (L.) Moench) PADA SISTEM TUMPANGSARI DENGAN UBI KAYU (Manihot esculenta Crantz)
}

\author{
C.G.E Sitorus, Sunyoto, M. Syamsoel Hadi \& M. Kamal \\ Jurusan Agroteknologi, Fakultas Pertanian, Universitas Lampung \\ Jl. Soemantri Brodjonegoro No. 1 Bandar Lampung 35143 \\ E-mail: gombenezer@gmail.com
}

\begin{abstract}
ABSTRAK
Penelitian ini bertujuan untuk mengetahui pengaruh tingkat kerapatan tanaman, perbedaan varietas, dan interaksi antara tingkat kerapatan tanaman dan varietas tanaman sorgum terhadap pertumbuhan dan hasil tanaman sorgum yang ditumpangsarikan dengan ubi kayu. Penelitian ini dilaksanakan di Kebun Percobaaan BPTP (Balai Pengkajian Teknologi Pertanian) Natar, Lampung Selatan, pada bulan Agustus 2014 sampai November 2014. Perlakuan disusun secara faktorial dalam Rancangan Acak Kelompok, dengan 3 ulangan. Faktor pertama adalah varietas yang terdiri dari varietas Numbu, Keller dan Wray. Faktor kedua adalah kerapatanan tanaman yang terdiri dari kerapatan satu, sua, tiga, dan empat tanaman per lubang tanam. Petak percobaan pada penelitian ini berukuran $5 \mathrm{~m} \mathrm{x} 4 \mathrm{~m}$. Hasil penelitian menunjukkan bahwa kerapatan tanaman mempengaruhi komponen pertumbuhan dan komponen hasil tanaman sorgum pada sistem tumpangsari dengan ubi kayu. Varietas tanaman sorgum berpengaruh pada beberapa komponen pertumbuhan tanaman sorgum dan secara nyata mempengaruhi hasil tanaman sorgum. Varietas Numbu memberikan hasil yang terbaik bila dibandingkan dengan Varietas Keller dan Wray. Kombinasi antara varietas dan kerapatan tanaman berpengaruh terhadap komponen pertumbuhan dan hasil tanaman sorgum. Penggunaan Varietas Numbu dengan kerapatan 2 tanaman/ lubang menunjukkan pertumbuhan tanaman yang lebih baik dibanding dengan kedua lainnya, dan penggunaan Varietas Keller dengan kerapatan 1 tanaman/ lubang menunjukkan bobot berangkasan tertinggi (410 gram per tamanan) dibandingkan yang lainnya.
\end{abstract}

Kata kunci: hasil, kerapatan tanaman, pertumbuhan, sorgum, tumpangsari, varietas

\section{PENDAHULUAN}

Sorgum (Sorghum bicolor (L.) Moench) merupakan tanaman serealia yang dapat tumbuh pada berbagai keadaan lingkungan sehingga potensial dikembangkan khususnya pada lahan marginal beriklim kering di Indonesia. Sorgum mempunyai potensi penting sebagai sumber karbohidrat bahan pangan, pakan, dan komoditi ekspor. Sebagai bahan pangan sorgum biasanya dikonsumsi dalam bentuk roti, bubur dan minuman (sirup). Sebagai pakan dimanfaatkan bijinya, batang dan daunnya diberikan dalam bentuk green chop, hay dan silase. Untuk industri dijadikan bahan perekat, pelet pakan ternak atau industri gula (Irwan, dkk., 2004). Tanaman sorgum juga dapat diratoon dimana dapat dilakukan untuk meningkatkan hasil produksi, karena menurut Alfandi (2006) ratoon merupakan salah satu cara untuk meningkatkan hasil tanaman per satuan luas lahan dan per satuan waktu. Tanaman sorgum termasuk dalam tanaman semusim dan dapat dipanen saat berumur tiga bulan, dimana hal tersebut dapat dimanfaatkan untuk dilakukannya tumpangsari.

Tumpangsari merupakan suatu usaha menanam beberapa jenis tanaman pada lahan dan waktu yang sama, yang diatur sedemikian rupa dalam barisan-barisan tanaman. Penanaman dengan cara ini bisa dilakukan pada dua atau lebih jenis tanaman yang relatif seumur, misalnya jagung dan kacang tanah atau pada beberapa jenis tanaman yang umurnya berbeda-beda (Warsana, 2009). Tumpangsari antara tanaman sorgum dengan ubikayu dapat dilakukan untuk meningkatkan hasil produksi pertanian yang mana kedua memiliki potensi produksi yang baik. Selain menggunakan teknologi tumpangsari, tanaman sorgum dapat dilakukan dengan meningkatkan kerapatan tanaman pada tiap lubang tanam tanaman sorgum.

Teknik budidaya dengan meningkatkan kerapatan tanaman pada tanaman sorgum merupakan upaya peningkatan hasil produksi. Menurut Atusa'diyah (2004) penentuan kerapatan tanam pada suatu areal 
pertanaman pada hakekatnya merupakan salah satu cara untuk mendapatkan hasil tanaman secara maksimal. Namun, meningkatkan kerapatan tanaman pada tiap lubang akan menimbulkan persaingan antara tanaman sorgum tersebut. Salisbury dan Ross (1985) menyatakan bahwa populasi yang tinggi menimbulkan persaingan antar tanaman. Salah satu persaingan yang terjadi adalah persaingan dalam memperebutkan cahaya matahari. Lakitan (1993) dikutip oleh Zulkarnain (2005) menyebutkan bahwa pada populasi tanaman yang lebih sedikit, tingkat persaingan untuk mendapatkan cahaya matahari lebih rendah, akan terjadi peningkatan laju fotosintesis karena terjadi penangkapan energi cahaya matahari yang lebih besar. Jika kondisi lingkungan menguntungkan, hasil sorgum masih dapat ditingkatkan dengan meningkatnya bobot biji. Kekeringan pada tahap ini dapat mengakibatkan menurunnya pengisian biji (Vanderlip, dkk., 1972). Sebaliknya, jika peningkatan kerapatan tanaman pada tiap lubang tanam dilakukan persaingan antar tanaman semakin tinggi yang mana dalam penyerapan cahaya matahari, unsur hara, serta air pada tiap tanaman rendah.

Penggunaan varietas pada tanaman sangat penting dilakukan untuk mengetahui potensi yang terdapat didalam suatau tanaman dalam mengekspresikan lingkungan tumbuh yang terdapat disekitarnya. Menurut Efendi, dkk. (2013), faktor gen merupakan faktor penurunan sifat pada keturunan yang terkandung di dalam genotipe. Informasi genetik pada gen mengendalikan terbentuknya penampakan sifat fisik melalui interaksinya dengan lingkungan. Penggunaan perbedaan varietas tanaman dengan menambahkan kerapatan tanaman pada tiap lubang tanam tentunya akan ditunjukkan oleh tanaman.

Tingkat kerapatan tanaman yang dilakukan bergantung pada jenis atau varietas tanaman sorgum. Pithaloka (2014) menyatakan bahwa tanaman sorgum yang ditanam dengan tingkat kerapatan tanaman hingga 4 tanaman per lubang tanam sangat mempengaruhi pertumbuhan dan komponen hasil tanaman sorgum. Pemilihan Varietas Numbu untuk produksi dengan kerapatan tanaman tinggi (4 tanaman/lubang) pada sistem tanam monokultur menghasilkan produksi sorgum yang lebih baik dibandingkan dengan kerapatan tanaman rendah (1-2 tanaman/ lubang). Namun, interaksi antara kerapatan tanaman dan varietas pada sistem tanam tumpangsari dengan ubikayu pada sistem tanam tumpangsari dengan ubikayu belum dilaporkan, oleh karena itu informasi pengaruh tingkat kerapatan tanaman terhadap hasil sorgum pada sistem tanam tumpangsari perlu dilakukan secara cermat. Informasi ini sangat bermanfaat dalam pengembangan sorgum melalui sistem tumpangsari dengan ubikayu.

Penelitian ini bertujuan untuk mengetahui pengaruh tingkat kerapatan tanaman, perbedaan varietas, dan interaksi antara tingkat kerapatan tanaman dan varietas tanaman sorgum terhadap pertumbuhan dan hasil tanaman sorgum yang ditumpangsarikan dengan ubi kayu.

\section{BAHAN DAN METODE}

Penelitian ini dilaksanakan di Kebun Percobaaan BPTP (Balai Pengkajian Teknologi Pertanian) Natar, Lampung Selatan, dan Laboratorium Agronomi, Fakultas Pertanian, Universitas Lampung, pada bulan Agustus 2014 sampai November 2014. Bahan-bahan dan alat yang digunakan adalah tiga varietas sorgum (Numbu, Keller, dan Wray), pupuk Urea, SP36, KCl, alat pengolah tanah (bajak singkal dan bajak rotari), tali raffia, alat penugal, meteran, selang, koret, cangkul, timbangan, kamera, jangka sorong, klorofilmeter, seed counter, moisture meter, alat penyedot air, label, oven dan alat tulis. Penelitian ini menggunakan rancangan perlakuan pola faktorial $(3 \times 4)$ dalam Rancangan Acak Kelompok (RAK) dengan tiga ulangan. Faktor pertama adalah kerapatan tanaman $(\mathrm{P})$ dibagi menjadi 4 taraf, yaitu satu (p1), dua (p2), tiga (p3), dan empat (p4) tanaman/lubang tanam sedangkan faktor kedua, varietas $(\mathrm{G})$ ada tiga, yaitu Numbu (g1), Keller (g2) dan Wray (g3). Dengan kombinasi perlakuan antara lain: g1p1, g1p2, g1p3, g1p4, g2p1, g2p2, g2p3, g2p4, g3p1, g3p2, g3p3, g3p4.

Homogenitas ragam diuji dengan uji Bartlet, aditivitas data diuji dengan uji Tukey, bila asumsi terpenuhi data dianalisis dengan analisis ragam, dan perbedaan nilai tengah diuji dengan Uji Beda Nyata Terkecil (BNT) pada taraf nyata $5 \%$. Pengolahan tanah, pembuatan petakan berukuran $5 \mathrm{~m} \mathrm{x} 4 \mathrm{~m}$, dan jarak tanam yang digunaan untuk sogum yaitu $80 \mathrm{~cm}$ x 20 $\mathrm{cm}$, sedangkan untuk ubi kayu $80 \mathrm{~cm} \times 60 \mathrm{~cm}$. Pemupukan menggunakan pupuk kimia urea, SP36, dan KCl. Pemupukan yang dilakukan pada percobaan ini dibagi menjadi dua kali pemupukan. Pemupukan tanaman sorgum dengan pupuk dan dosis yang digunakan adalah pupuk urea, SP-36, dan $\mathrm{KCl}$ masing - masing 200, 100 dan $100 \mathrm{~kg} / \mathrm{ha}$. Pemberian pupuk dilakukan sebanyak dua kali, pemupukan pertama urea : SP-36 : KCl sebanyak $1 / 2: 1: 1$ bagian yang diberikan pada umur dua minggu setelah tanam. Pemupukan dilakukan sebanyak dua kali terhadap pupuk urea, yaitu pemupukan kedua pada saat tanaman berumur enam minggu.

Jumlah tanaman yang diamati adalah 3 tanaman setiap petak yang dipilih secara acak. Parameter yang 
diamati pada komponen tumbuh ini meliputi tinggi tanaman, jumlah daun, diameter batang, tingkat kehijauan daun, umur berbunga, panjang malai, bobot malai, jumlah biji/malai, bobot 100 butir biji kering, bobot berangkasan basah, bobot berangkasan kering, bobot biji $/ \mathrm{malai} / \mathrm{m}^{2}$.

\section{HASIL DAN PEMBAHASAN}

Hasil penelitian tentang pertumbuhan dan hasil tanaman sorgum pada sistem tumpangsari dengan ubikayu dengan perbedaan varietas dan kerapatan tanaman dapat dilihat pengaruhnya dari berbagai variabel pertumbuhan dan komponen hasil dan hasil biji. Perbedaan varietas dan kerapatan tanaman sorgum pada sistem tumpangsari dengan ubi kayu berpengaruh nyata pada beberapa komponen hasil. Penggunaan varietas pada sistem tumpangsari akan menentukan hasil dari masing-masing tanaman. Hasil penelitian menunjukkan penggunaan perbedaan varietas tanaman sorgum pada sistem tumpangsari dengan ubi kayu berpengaruh pada seluruh komponen hasil tanaman sorgum.

Pertumbuhan tanaman yang berbeda akan menghasilkan produksi yang berbeda pula pada setiap varietasnya, pada seluruh variabel hasil tanaman sorgum berpengaruh terhadap varietas yang diuji. Varietas sorgum dalam penelitian ini memiliki sifat dan pertumbuhan yang berbeda-beda. Pertumbuhan tanaman sorgum pada Varietas Numbu (Tabel 1, 2, 3, 4, 5, dan 6) menunjukkan pertumbuhan yang baik bila dibandingkan dengan kedua varietas lainnya. Selain menunjukkan pertumbuhan yang berbeda, varietas juga

Tabel 1. Interaksi antara kerapatan tanaman dan varietas terhadap tinggi tanaman sorgum pada umur 7 mst.

\begin{tabular}{|c|c|c|c|c|c|}
\hline \multirow{3}{*}{ Varietas Sorgum } & \multicolumn{4}{|c|}{ Kerapatan (tanaman/lubang) } & \multirow{3}{*}{ BNT 5\% } \\
\hline & 1 & 2 & 3 & 4 & \\
\hline & \multicolumn{4}{|c|}{$\ldots \ldots \ldots \ldots \ldots \ldots \ldots, c m . \ldots \ldots \ldots \ldots \ldots \ldots$} & \\
\hline Numbu & $\begin{array}{c}86,78 \text { b } \\
\text { B }\end{array}$ & $\begin{array}{c}146,00 \mathrm{a} \\
\mathrm{A}\end{array}$ & $\begin{array}{c}114,52 \mathrm{ab} \\
\mathrm{A}\end{array}$ & $\begin{array}{c}112,09 \mathrm{ab} \\
\mathrm{A}\end{array}$ & \\
\hline Keller & $\begin{array}{c}123,56 \mathrm{a} \\
\mathrm{A}\end{array}$ & $\begin{array}{c}113,14 \mathrm{a} \\
\mathrm{B}\end{array}$ & $\begin{array}{c}110,09 \mathrm{a} \\
\mathrm{A}\end{array}$ & $\begin{array}{c}93,42 \mathrm{a} \\
\mathrm{A}\end{array}$ & 42,97 \\
\hline Wray & $\begin{array}{c}127,00 \mathrm{a} \\
\mathrm{A}\end{array}$ & $\begin{array}{c}100,45 \mathrm{a} \\
\mathrm{B}\end{array}$ & $\begin{array}{c}98,51 \mathrm{a} \\
\mathrm{A}\end{array}$ & $\begin{array}{c}96,33 \mathrm{a} \\
\mathrm{A}\end{array}$ & \\
\hline
\end{tabular}

BNT 5\% 29,29

Keterangan : Angka yang diikuti huruf yang sama tidak berbeda nyata berdasarkan uji BNT 5\%. Huruf besar perbandingan vertikal dan huruf kecil perbandingan horizontal.

Tabel 2. Interaksi antara kerapatan tanaman dan varietas terhadap tinggi tanaman sorgum pada umur 8 mst.

\begin{tabular}{|c|c|c|c|c|c|}
\hline \multirow[b]{2}{*}{ Varietas Sorgum } & \multicolumn{4}{|c|}{ Kerapatan (tanaman/lubang) } & \multirow{3}{*}{ BNT $5 \%$} \\
\hline & 1 & 2 & 3 & 4 & \\
\hline & \multicolumn{4}{|c|}{ 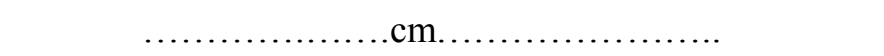 } & \\
\hline Numbu & $\begin{array}{c}95,72 b \\
B\end{array}$ & $\begin{array}{c}144,84 \mathrm{a} \\
\mathrm{A}\end{array}$ & $\begin{array}{c}114,02 \mathrm{ab} \\
\mathrm{A}\end{array}$ & $\begin{array}{c}112,73 \mathrm{~b} \\
\mathrm{~A}\end{array}$ & \\
\hline Keller & $\begin{array}{c}137,78 \mathrm{a} \\
\mathrm{A}\end{array}$ & $\begin{array}{c}125,33 \mathrm{a} \\
\mathrm{AB}\end{array}$ & $\begin{array}{c}119,44 \mathrm{a} \\
\mathrm{A}\end{array}$ & $\begin{array}{c}100,61 \mathrm{a} \\
\mathrm{A}\end{array}$ & 46,19 \\
\hline Wray & $\begin{array}{c}141,90 \mathrm{a} \\
\mathrm{A}\end{array}$ & $\begin{array}{c}111,13 \mathrm{a} \\
\mathrm{B}\end{array}$ & $\begin{array}{c}109,01 \mathrm{a} \\
\mathrm{A}\end{array}$ & $\begin{array}{c}108,63 \mathrm{a} \\
\mathrm{A}\end{array}$ & \\
\hline
\end{tabular}

BNT $5 \%$

Keterangan : Angka yang diikuti huruf yang sama tidak berbeda nyata berdasarkan uji BNT 5\%. Huruf besar perbandingan vertikal dan huruf kecil perbandingan horizontal. 
Tabel 3. Interaksi antara kerapatan tanaman dan varietas terhadap jumlah daun tanaman sorgum pada umur 8 mst.

\begin{tabular}{|c|c|c|c|c|c|}
\hline \multirow{3}{*}{ Varietas Sorgum } & \multicolumn{4}{|c|}{ Kerapatan (tanaman/lubang) } & \multirow{3}{*}{ BNT 5\% } \\
\hline & 1 & 2 & 3 & 4 & \\
\hline & \multicolumn{4}{|c|}{..................helai..................... } & \\
\hline \multirow[t]{2}{*}{ Numbu } & 8,89 a & $10,84 \mathrm{a}$ & $9,54 \mathrm{a}$ & $9,47 \mathrm{a}$ & \multirow{6}{*}{2,11} \\
\hline & B & A & A & $\mathrm{A}$ & \\
\hline \multirow[t]{2}{*}{ Keller } & 10,44 a & $9,06 \mathrm{ab}$ & $8,26 \mathrm{~b}$ & $7,08 \mathrm{~b}$ & \\
\hline & A & B & A & B & \\
\hline \multirow{2}{*}{ Wray } & $9,89 \mathrm{a}$ & $8,72 \mathrm{a}$ & $8,33 \mathrm{a}$ & $8,28 \mathrm{a}$ & \\
\hline & $\mathrm{AB}$ & B & A & $\mathrm{AB}$ & \\
\hline BNT 5\% & 1,44 & & & & \\
\hline
\end{tabular}

Keterangan: Angka yang diikuti huruf yang sama tidak berbeda nyata berdasarkan uji BNT 5\%. Huruf besar perbandingan vertikal dan huruf kecil perbandingan horizontal.

Tabel 4. Interaksi antara kerapatan tanaman dan varietas terhadap diameter batang tanaman sorgum pada umur 7 mst.

\begin{tabular}{|c|c|c|c|c|c|}
\hline \multirow[b]{2}{*}{ Varietas Sorgum } & \multicolumn{4}{|c|}{ Kerapatan (tanaman/lubang) } & \multirow{3}{*}{ BNT $5 \%$} \\
\hline & 1 & 2 & 3 & 4 & \\
\hline & \multicolumn{4}{|c|}{. } & \\
\hline Numbu & $\begin{array}{c}1,36 \mathrm{ab} \\
\mathrm{B}\end{array}$ & $\begin{array}{c}1,56 \mathrm{a} \\
\mathrm{A}\end{array}$ & $\begin{array}{c}1,24 \mathrm{ab} \\
\mathrm{A}\end{array}$ & $\begin{array}{c}1,21 \mathrm{~b} \\
\mathrm{~A}\end{array}$ & \multirow{4}{*}{0,33} \\
\hline Keller & $\begin{array}{c}1,83 \mathrm{a} \\
\mathrm{A}\end{array}$ & $\begin{array}{c}1,55 \mathrm{ab} \\
\mathrm{A}\end{array}$ & $\begin{array}{c}1,43 \mathrm{ab} \\
\mathrm{A}\end{array}$ & $\begin{array}{c}1,23 \mathrm{ab} \\
\mathrm{A}\end{array}$ & \\
\hline Wray & $1,88 \mathrm{a}$ & $1,48 \mathrm{~b}$ & $1,35 \mathrm{~b}$ & $1,27 \mathrm{~b}$ & \\
\hline & $\mathrm{A}$ & A & A & $\mathrm{A}$ & \\
\hline
\end{tabular}

Keterangan: Angka yang diikuti huruf yang sama tidak berbeda nyata berdasarkan uji BNT 5\%. Huruf besar perbandingan vertikal dan huruf kecil perbandingan horizontal.

Tabel 5. Interaksi antara kerapatan tanaman dan varietas terhadap diameter batang tanaman sorgum pada umur 8 mst.

\begin{tabular}{|c|c|c|c|c|c|}
\hline \multirow[b]{2}{*}{ Varietas Sorgum } & \multicolumn{4}{|c|}{ Kerapatan (tanaman/lubang) } & \multirow{3}{*}{ BNT 5\% } \\
\hline & 1 & 2 & 3 & 4 & \\
\hline & \multicolumn{4}{|c|}{ 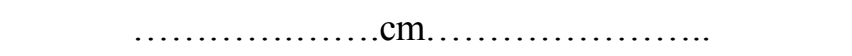 } & \\
\hline Numbu & $1,37 \mathrm{a}$ & $1,47 \mathrm{a}$ & $1,16 b$ & $1,16 \mathrm{~b}$ & \multirow{6}{*}{0,28} \\
\hline & $\mathrm{B}$ & A & B & A & \\
\hline Keller & $1,92 \mathrm{a}$ & $1,51 \mathrm{~b}$ & $1,41 \mathrm{~b}$ & $1,24 \mathrm{~b}$ & \\
\hline & A & A & A & A & \\
\hline \multirow{2}{*}{ Wray } & $1,86 \mathrm{a}$ & $1,48 \mathrm{~b}$ & $1,35 \mathrm{~b}$ & $1,30 \mathrm{~b}$ & \\
\hline & A & A & $\mathrm{AB}$ & A & \\
\hline
\end{tabular}

Keterangan: Angka yang diikuti huruf yang sama tidak berbeda nyata berdasarkan uji BNT 5\%. Huruf besar perbandingan vertikal dan huruf kecil perbandingan horizontal. 
Tabel 6. Interaksi antara kerapatan tanaman dan varietas terhadap bobot biji per malai tanaman sorgum.

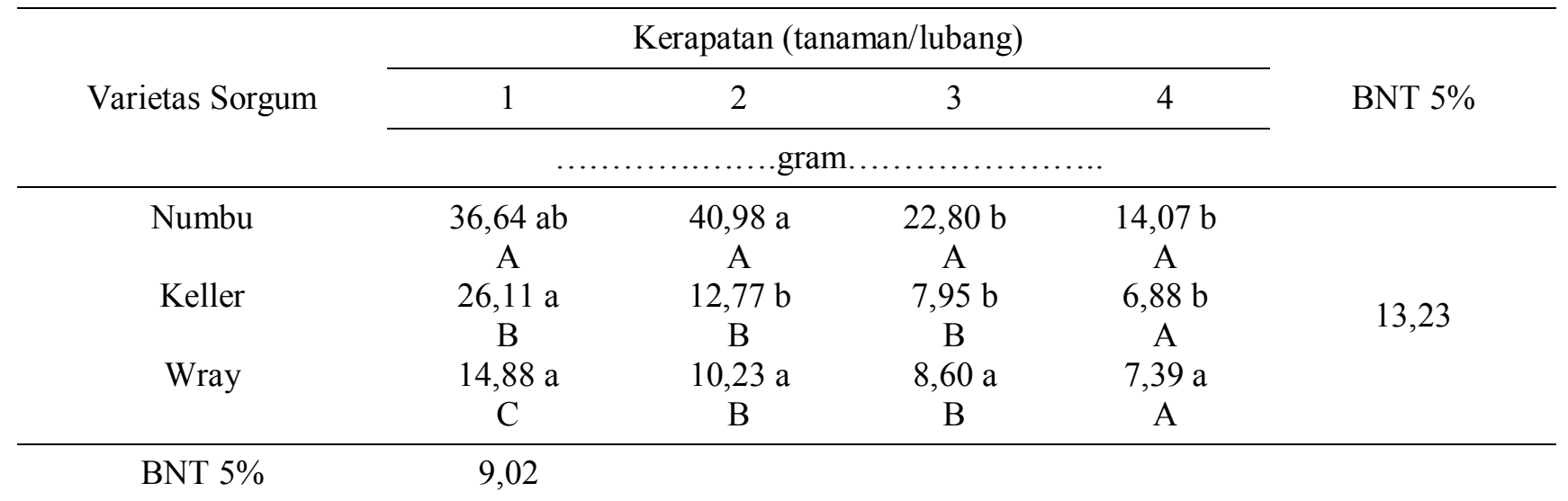

Keterangan: Angka yang diikuti huruf yang sama tidak berbeda nyata berdasarkan uji BNT 5\%. Huruf besar perbandingan vertikal dan huruf kecil perbandingan horizontal.

berpengaruh secara nyata terhadap hasil tanaman sorgum (Tabel 7, 8, dan 9) Varietas Numbu menghasilkan jumlah biji per malai tertinggi 1259 butir per tanaman yang apabila dikonversi dalam satuan luas dimana akan menghasilkan jumlah tertinggi kembali yang ditunjukkan oleh Varietas Numbu. Varietas Keller menghasilkan bobot berangkasan tertinggi bila dibandingkan dengan kedua varietas yang lainnya, yaitu 410 gram per tanaman pada kerapatan tanaman rendah (1 tanaman/ lubang tanam).

Perbedaan pertumbuhan dan hasil tanaman sorgum dipengaruhi oleh perbedaan kerapatan tanaman juga dipengaruhi oleh varietas dari tanaman tersebut secara tunggal. Seperti yang dinyatakan Budiman (2005) yang dikutip oleh Efendi, dkk. (2013) yaitu faktor gen merupakan faktor penurunan sifat pada keturunan yang terkandung di dalam genotipe. Informasi genetik pada gen mengendalikan terbentuknya penampakan sifat fisik melalui interaksinya dengan lingkungan.

Pada Tabel 10. umur berbunga tanaman sorgum ditunjukkan oleh Varietas Numbu (73,41 hari) lebih cepat berbunga dibandingkan dengan varietas yang lainnya. Pada panjang malai Varietas Keller memberikan panjang malai yang paling panjang dibandingkan dengan dua varietas lainnya yaitu $22,58 \mathrm{~cm}$. Sedangkan untuk bobot 100 butir biji kering Varietas Numbu memberikan bobot biji yang paling baik yaitu 3,13 gram dibandingkan dengan Varietas Keller 2,03 gram dan Wray 2,14 gram. Pada bobot berangkasan basah Varietas Numbu memberikan bobot terberat dengan 92,10 gram.

Kerapatan tanaman merupakan pengaturan jumlah populasi per lubang tanam. Pada Tabel 11, kerapatan tanaman satu lubang per lubang tanam menunjukkan pertumbuhan yang lebih baik dibandingkan tiga kerapatan lainnya. Kerapatan tanaman dilakukan agar lahan yang terbatas dapat dioptimalkan hasil produksinya sehingga hasil produksi dapat di capai secara maksimal. Hal ini tentunya akan membuat kompetisi antar tanaman dalam memperebutkan ruang tumbuh, unsur hara, air, dan intersepsi cahaya yang diperlukan pada masing-masing tanaman. Semakin banyak populasi perlubang tanam yang digunakan maka semakin besar persaingan yang terjadi diantara tanaman.

Peningkatan jumlah tanaman per lubang tanam akan mengakibatkan kompetisi antar tanaman pada lubang tanam tersebut yang menghasilkan hasil tanaman menjadi berkurang, seperti pada variabel bobot biji per malai, semakin tinggi kerapatan tanaman maka bobot biji per malai akan semakin rendah. Hal tersebut ditunjukkan pada Tabel 8. pada Varietas Numbu dengan tingkat kerapatan satu dan dua tanaman per lubang tanam menghasilkan bobot biji per malai 36,64 gram dan 40,98 gram lebih tinggi bila dibandingkan dengan tingkat kerapatan tiga dan empat tanaman per lubang tanam yaitu 22,80 gram dan 14,70 gram. Demikian juga ditunjukkan untuk Varietas Keller dan Wray yang memiliki bobot biji per malai dengan tingkat kerapatan tanaman satu dan dua tanaman per lubang tanam lebih tinggi bila dibandingkan tingkat kerapatan tanaman tiga dan empat tanaman per lubang tanam.

Sesuai dengan pernyataan Gardner, dkk. (1991) yang menyatakan bahwa kerapatan tanaman mempengaruhi pertumbuhan tanaman, yang disebabkan karena penyerapan energi matahari oleh permukaan daun yang menentukan pertumbuhan tanaman. Apabila kondisi tanaman terlalu rapat maka akan menyebabkan terhambatnya perkembangan vegetatif dan menurunkan 
Tabel 7. Interaksi antara kerapatan tanaman dan varietas terhadap jumlah biji/ malai tanaman sorgum.

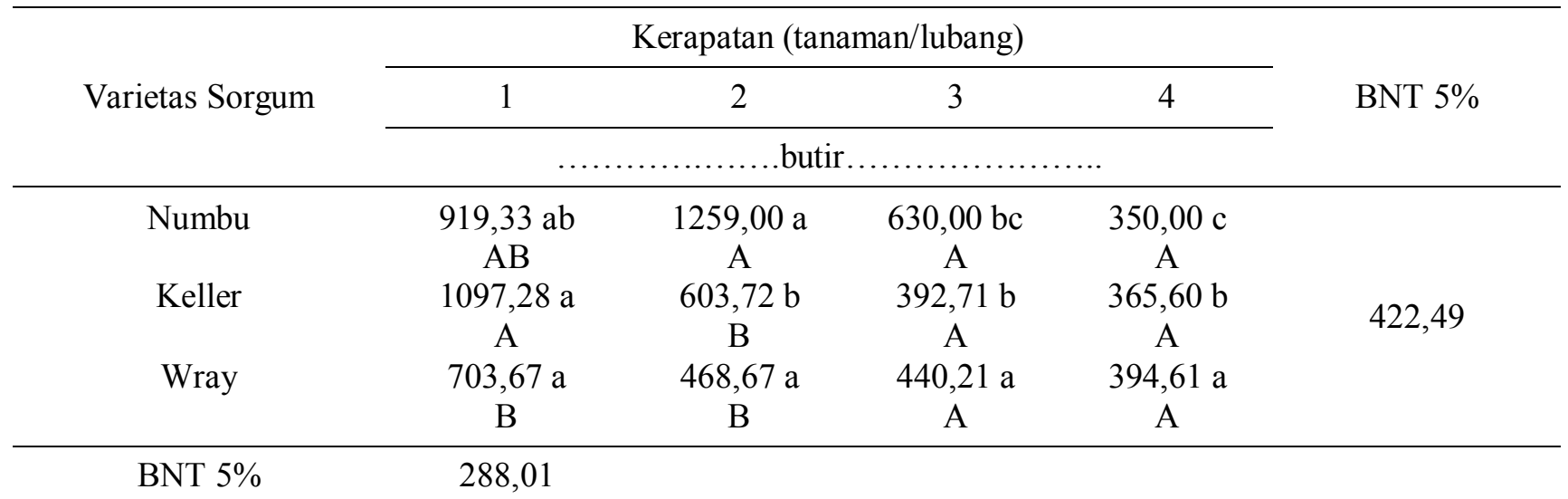

Keterangan: Angka yang diikuti huruf yang sama tidak berbeda nyata berdasarkan uji BNT 5\%. Huruf besar perbandingan vertikal dan huruf kecil perbandingan horizontal.

Tabel 8. Interaksi antara kerapatan tanaman dan varietas terhadap bobot berangkasan basah tanaman sorgum.

\begin{tabular}{|c|c|c|c|c|c|}
\hline \multirow{3}{*}{ Varietas Sorgum } & \multicolumn{4}{|c|}{ Kerapatan (tanaman/lubang) } & \multirow{3}{*}{ BNT 5\% } \\
\hline & 1 & 2 & 3 & 4 & \\
\hline & \multicolumn{4}{|c|}{$\ldots \ldots \ldots \ldots \ldots \ldots \ldots$ gram per $\tan a m a n . \ldots \ldots \ldots \ldots \ldots \ldots \ldots$} & \\
\hline Numbu & $\begin{array}{c}262,83 \mathrm{a} \\
\mathrm{B}\end{array}$ & $\begin{array}{c}244,67 \mathrm{a} \\
\mathrm{A}\end{array}$ & $\begin{array}{c}123,11 \mathrm{~b} \\
\mathrm{~A}\end{array}$ & $\begin{array}{c}121,75 \mathrm{~b} \\
\mathrm{~A}\end{array}$ & \\
\hline Keller & $\begin{array}{c}410,00 \mathrm{a} \\
\mathrm{A}\end{array}$ & $\begin{array}{c}218,14 b \\
A\end{array}$ & $\begin{array}{c}162,33 \mathrm{~b} \\
\mathrm{~A}\end{array}$ & $\begin{array}{c}153,83 \mathrm{~b} \\
\mathrm{~A}\end{array}$ & 105,60 \\
\hline Wray & $\begin{array}{c}386,72 \mathrm{a} \\
\mathrm{A}\end{array}$ & $\begin{array}{c}218,00 \mathrm{~b} \\
\mathrm{~A}\end{array}$ & $\begin{array}{c}172,26 \mathrm{~b} \\
\mathrm{~A}\end{array}$ & $\begin{array}{c}169,69 \mathrm{~b} \\
\mathrm{~A}\end{array}$ & \\
\hline
\end{tabular}

BNT $5 \%$

Keterangan: Angka yang diikuti huruf yang sama tidak berbeda nyata berdasarkan uji BNT 5\%. Huruf besar perbandingan vertikal dan huruf kecil perbandingan horizontal.

Tabe1 9. Interaksi antara kerapatan tanaman dan varietas terhadap bobot biji tanaman sorgum dalam satuan luas $\left(\mathrm{m}^{2}\right)$.

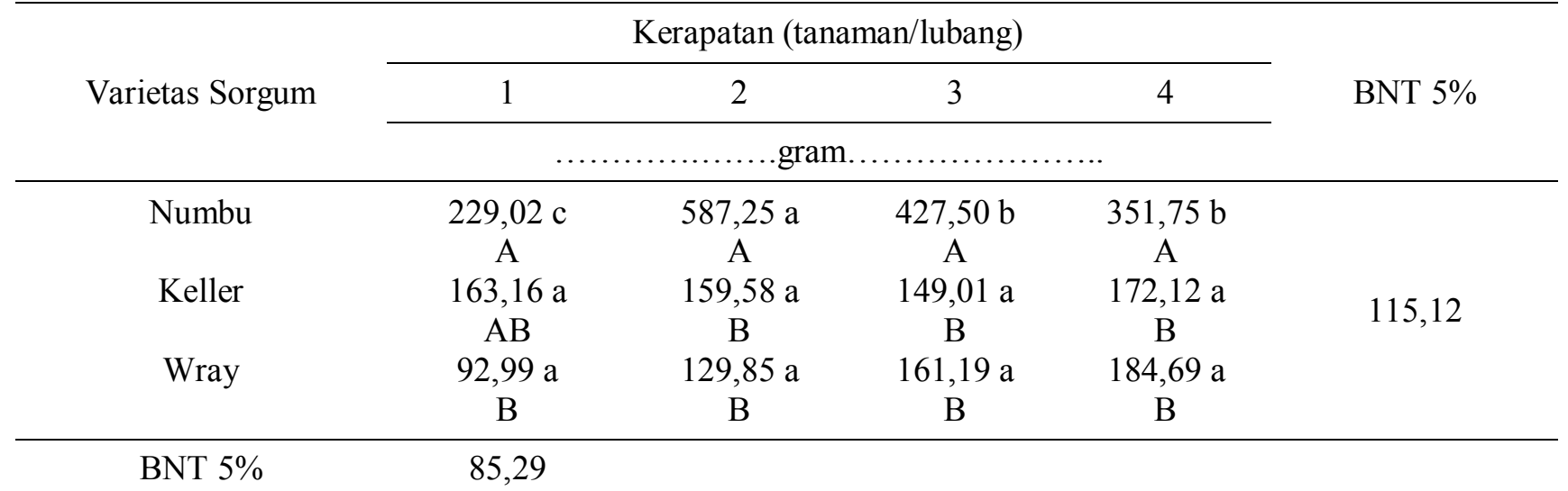

Keterangan: Angka yang diikuti huruf yang sama tidak berbeda nyata berdasarkan uji BNT 5\%. Huruf besar perbandingan vertikal dan huruf kecil perbandingan horizontal. 
Tabel 10. Pengaruh varietas sorgum dan kerapatan tanaman terhadap umur berbunga, panjang malai, bobot biji/ malai dan bobot 100 butir biji kering.

\begin{tabular}{lcccc}
\hline \multicolumn{1}{c}{ Pelakuan } & $\begin{array}{c}\text { Umur } \\
\text { berbunga }\end{array}$ & $\begin{array}{c}\text { Panjang } \\
\text { malai }\end{array}$ & $\begin{array}{c}\text { Bobot } 100 \text { butir } \\
\text { biji kering }\end{array}$ & $\begin{array}{c}\text { Bobot berangkasan } \\
\text { basah }\end{array}$ \\
\hline Varietas Sorgum & & & & \\
\hline Numbu & $73,41 \mathrm{~b}$ & $13,95 \mathrm{c}$ & $3,13 \mathrm{a}$ & $92,10 \mathrm{a}$ \\
Keller & $88,50 \mathrm{a}$ & $22,58 \mathrm{a}$ & $2,03 \mathrm{~b}$ & $88,25 \mathrm{a}$ \\
Wray & $83,66 \mathrm{a}$ & $20,09 \mathrm{~b}$ & $2,14 \mathrm{~b}$ & $68,72 \mathrm{~b}$ \\
\hline BNT 5\% & 6,46 & 1,82 & 0,20 & 15,71 \\
\hline Kerapatan (Tanaman /lubang) & & & $2,59 \mathrm{a}$ & \\
\hline \multicolumn{1}{c}{1} & $82,77 \mathrm{a}$ & $22,39 \mathrm{a}$ & $2,54 \mathrm{ab}$ & $90,36 \mathrm{~b}$ \\
\multicolumn{1}{c}{3} & $81,55 \mathrm{a}$ & $18,90 \mathrm{~b}$ & $2,33 \mathrm{bc}$ & $56,45 \mathrm{c}$ \\
4 & $80,88 \mathrm{a}$ & $17,49 \mathrm{bc}$ & $2,28 \mathrm{c}$ & $49,09 \mathrm{c}$ \\
\hline BNT 5\% & $82,55 \mathrm{a}$ & $16,71 \mathrm{c}$ & 0,24 & 18,14 \\
\hline
\end{tabular}

Keterangan: Angka yang diikuti huruf yang sama tidak berbeda nyata berdasarkan uji BNT 5\%. Huruf besar perbandingan vertikal dan huruf kecil perbandingan horizontal.

Tabel 11. Pengaruh varietas dan kerapatan tanaman terhadap tinggi tanaman sorgum pada umur 4, 5, 6, 7 dan 8 mst.

\begin{tabular}{|c|c|c|c|c|c|}
\hline \multirow{2}{*}{ Perlakuan } & \multicolumn{5}{|c|}{ Umur Tanaman (mst) } \\
\hline & 4 & 5 & 6 & 7 & 8 \\
\hline Varietas Sorgum & \multicolumn{5}{|c|}{ 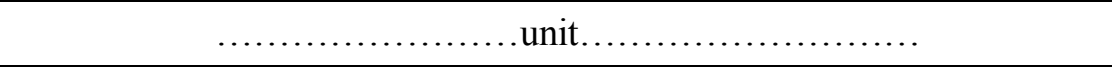 } \\
\hline Numbu & $33,27 \mathrm{a}$ & $31,89 \mathrm{~b}$ & $35,76 \mathrm{a}$ & $35,37 \mathrm{a}$ & $36,73 \mathrm{a}$ \\
\hline Keller & $34,24 \mathrm{a}$ & 33,92 a & 36,55 a & 35,97 a & $35,66 \mathrm{a}$ \\
\hline Wray & $34,65 \mathrm{a}$ & $32,62 \mathrm{ab}$ & 35,69 a & 35,08 a & $35,64 \mathrm{a}$ \\
\hline BNT 5\% & 3,28 & 1,50 & 1,80 & 2,04 & 1,87 \\
\hline \multicolumn{6}{|c|}{ Kerapatan (tanaman/lubang) } \\
\hline 1 & $34,65 \mathrm{a}$ & $34,38 \mathrm{a}$ & $39,86 \mathrm{a}$ & $39,56 \mathrm{a}$ & $39,17 \mathrm{a}$ \\
\hline 2 & 34,68 a & $33,56 \mathrm{ab}$ & $36,75 \mathrm{~b}$ & $36,09 \mathrm{~b}$ & $36,78 \mathrm{~b}$ \\
\hline 3 & $33,49 \mathrm{a}$ & $32,39 \mathrm{bc}$ & $35,24 \mathrm{bc}$ & $34,36 \mathrm{~b}$ & $34,37 \mathrm{c}$ \\
\hline 4 & $33,40 \mathrm{a}$ & $30,90 \mathrm{c}$ & $33,49 \mathrm{c}$ & $31,81 \mathrm{c}$ & $33,71 \mathrm{c}$ \\
\hline BNT 5\% & 3,84 & 1,74 & 2,08 & 2,35 & 2,15 \\
\hline
\end{tabular}

Keterangan: Angka yang diikuti huruf yang sama tidak berbeda nyata berdasarkan uji BNT 5\%. Huruf besar perbandingan vertikal dan huruf kecil perbandingan horizontal.

hasil panen akibat menurunnya laju fotosintesis dan perkembangan daun.

Salisbury dan Ross (1985) menyatakan bahwa populasi yang tinggi menimbulkan persaingan antar tanaman yang menyebabkan batang tanaman diameternya semakin mengecil. Hal ini terjadi pada penelitian ini pada komponen pertumbuhan yakni diameter batang yang dapat dilihat pada Tabel 12 . kerapatan tinggi (4 tanaman/ lubang) memiliki diameter batang yang sangat kecil yaitu 1,15 dan kerapatan rendah (1 tanaman/ lubang) yaitu 1,67. Terdapat respons pada kombinasi antara kerapatan tanaman dengan varietas 
Tabel 12. Pengaruh varietas dan kerapatan tanaman terhadap diameter batang tanaman sorgum pada umur 6 mst.

\begin{tabular}{lc}
\hline \multirow{2}{*}{ Perlakuan } & Umur Tanaman (mst) \\
\cline { 2 - 2 } & 6 \\
\hline Varietas Sorgum & $\ldots \ldots . . \mathrm{cm} . \ldots .$. \\
\hline Numbu & $1,32 \mathrm{a}$ \\
Keller & $1,39 \mathrm{a}$ \\
Wray & $1,42 \mathrm{a}$ \\
\hline BNT 5\% & 0,14 \\
\hline Kerapatan (tanaman/lubang) & \\
\hline \multicolumn{1}{c}{1} & $1,67 \mathrm{a}$ \\
2 & $1,43 \mathrm{~b}$ \\
3 & $1,26 \mathrm{c}$ \\
4 & $1,15 \mathrm{c}$ \\
\hline BNT 5\% & 0,16 \\
\hline
\end{tabular}

Keterangan: Angka yang diikuti huruf yang sama tidak berbeda nyata berdasarkan uji BNT 5\%. Huruf besar perbandingan vertikal dan huruf kecil perbandingan horizontal.

tanaman sorgum pada sistem tumpang sari dengan ubikayu. Untuk interaksi antara varietas dan kerapatan tanaman didominansi oleh Varietas Numbu dengan kerapatan 2 tanaman/ lubang. Hal ini menyatakan bahwa Varietas Keller dengan kerapatan 2 tanaman/ lubang lebih baik apabila dibandingkan dengan varietas dan kerapatan lainnya.

Dari hasil penelitian ini menunjukan bahwa hasil tanaman sorgum pada sistem tumpangsari dengan ubikayu dalam satuan luas dengan varietas dan kerapatan tanaman tinggi 3 dan 4 tanaman/ lubang lebih tinggi bila dibandingkan dengan kerapatan tanaman rendah 2 dan 1 tanaman/ lubang. Berdasarkan bobot biji per malai per satuan luas $\left(\mathrm{m}^{2}\right)$ tanaman sorgum untuk seluruh varietas dengan kerapatan tinggi 3 dan 4 tanaman/ lubang masing-masing memiliki bobot biji lebih besar dibandingkan dengan kerapatan rendah 2 dan 1 tanaman/ lubang.

Penerapan sistem teknologi budidaya dengan pengaturan kerapatan tanaman dengan mengkombinasikan dengan varietas-varietas unggul yang memiliki kelebihan genetik masing-masing dengan sistem tumpangsari.akan berdampak positif terhadap optimalisasi lahan. Dalam penelitian ini Varietas Numbu dengan kerapatan tanaman 2 tanaman/ lubang dengan menggunakan jarak tanam $80 \mathrm{~cm}$ x $20 \mathrm{~cm}$ menghasilkan bobot biji/ malai tertinggi dengan hasil 46,98 gram bila dikonversikan dalam satuan hektar maka akan mendapatkan 125.000 populasi yang akan menghasilkan biji sorgum tertinggi hingga 5,87 ton/ha. Hal ini sangat menguntungkan apabila diterapkan langsung di masyarakat dan juga bila diterapkan pada sistem tumpangsari dimana kedua jenis tanaman yang ditumpangsari sama-sama menghasilkan dan mengurangi kegagalan panen diantara satu tanaman yang dibudidayakan, sehingga pemilihan tanaman sorgum dalam sistem tumpangsari sangat dianjurkan dan menguntungkan. Penggunaan varietas yang akan di tanam dengan kerapatan yang dipilih juga harus memperhatikan tujuannya, apabila yang akan dimanfaatkan adalah berangkasan atau biomassa yang dihasilkan untuk pakan ternak maka pemilihan Varietas Keller dengan kerapatan tanaman tinggi (3 dan 4 tanaman/lubang) yang lebih baik ditanam dengan jarak tanam $80 \mathrm{~cm} \times 20 \mathrm{~cm}$ yang akan menghasilkan bobot berangkasan basah tertinggi hingga 28,98 ton - 38,45 ton/ ha.

\section{KESIMPULAN}

Dari hasil penelitian disimpulkan bahwa Kerapatan tanaman mempengaruhi komponen pertumbuhan dan komponen hasil tanaman sorgum pada sistem tumpangsari dengan ubikayu. Varietas tanaman sorgum berpengaruh pada beberapa komponen pertumbuhan tanaman sorgum dan secara nyata mempengaruhi hasil tanaman sorgum. Varietas Numbu memberikan hasil yang terbaik bila dibandingkan dengan Varietas Keller dan Wray. Kombinasi antara varietas dan kerapatan tanaman berpengaruh terhadap komponen pertumbuhan dan hasil tanaman sorgum. Penggunaan Varietas Numbu dengan kerapatan 2 tanaman/ lubang menunjukan pertumbuhan tanaman yang lebih baik dibandingkan dengan dua varietas lainnya, dan penggunaan Varietas Keller dengan kerapatan 1 tanaman/ lubang menunjukan bobot berangkasan tertinggi dibandingkan yang lainnya.

\section{DAFTAR PUSTAKA}

Alfandi. 2006. Pengaruh tinggi pemangkasan (ratoon) dan pupuk nitrogen terhadap produksi padi (Oryza sativa L.) kultivar Ciherang. Jurnal Agrijati. 2: $1-7$. 
Atusa'diyah, M. 2004. Pertumbuhan dan Hasil Tanaman Buncis (Phaseolus vulgaris L) Tipe Tegak Pada Berbagai Variasi Kepadatan Tanaman dan Waktu Pemangkasan Pucuk. Skripsi. Fakultas Pertanian Universitas Brawijaya. Malang. 122 hal.

Efendi, R., M. Aqil, dan M. Pabendon. 2013. Evaluasi genotipe sorgum manis (Sorghum bicolor (L.) Moench) produksi biomas dan daya ratun tinggi. Jurnal Tanaman Pangan. 32(2): 116-125.

Gardner, F.P., R. B. Pearce, dan P. R. Michael. 1991. Fisiologi Tanaman Budidaya, Penterjemah Herawati Susilo. UI Press. Jakarta. 379 hal.

Irwan, W., A. Wahyudin, R. Susilawati, dan T. Nurmala. 2004. Interaksi jarak tanam dan jenis pupuk kandang terhadap komponen hasil dan kadar tepung sorghum (Sorghum bicolor L. Moench) pada Inceptisol di Jatinangor. Jurnal Budidaya Tanaman. 4:128-136.
Pithaloka, S.A. 2014. Pengaruh kerapatan tanaman terhadap pertumbuhan dan hasil beberapa varietas Sorgum (Sorghum bicolor (L.) Moench). Skripsi. Jurusan Agroteknologi. Fakultas Pertanian. Universitas Lampung: Bandar Lampung.

Salisbusry, F.B. dan C.W. Ross, 1995. Plant Physiology. Third Edition Wadsworth Publishing Company. Belmont: California. $540 \mathrm{p}$.

Warsana. 2009. Introduksi Teknologi Tumpangsari Jagung dan Kacang Tanah. Badan Litbang Pertanian.

Vanderlip, R. L. dan H.E. Reeves. 1972. Growth stages of sorghum (Sorghum bicolor (L.) Moench). Agr. J. 64(1):13-16.

Zulkarnain. 2005. Pertumbuhan dan hasil selada pada berbagai kerapatan jagung dalam pola tumpang sari. Jurnal Ilmu-ilmu Pertanian. 1 (2). 